\title{
Epithelial-mesenchymal transition in gastroenterological cancer
}

\author{
Hirohisa Okabe ${ }^{1}$, Kosuke Mima1, Seiya Saito', Hiromitsu Hayashi', Katsunori Imai', Hidetoshi Nitta', \\ Daisuke Hashimoto', Akira Chikamoto', Takatoshi Ishiko1, Toru Beppu², Hideo Baba1 \\ ${ }^{1}$ Department of Gastroenterological Surgery, Graduate School of Life Sciences, Kumamoto University, Kumamoto 860-8556, Japan. \\ ${ }^{2}$ Department of Multidisciplinary Treatment for Gastroenterological Cancer, Kumamoto University Hospital, Kumamoto 860-8556, Japan.
}

Correspondence to: Prof. Hideo Baba, Department of Gastroenterological Surgery, Graduate School of Life Science, Kumamoto University, 1-1-1 Honjo, Kumamoto City, Kumamoto 860-8556, Japan. Email: hdobaba@kumamoto-u.ac.jp

\section{A B S T R A C T}

Epithelial-mesenchymal transition (EMT) was first reported as an essential process in embryonic cells and later showed that cancer cells, regardless of the context, exhibited a similar phenomenon that was crucial for tumor progression. Epithelial cells lose their adhesive characteristic capacity which is necessary for their functions but gain a mesenchymal phenotype. This change from epithelial to the mesenchymal phenotype of cancer cells makes it difficult to understand the mechanism underlying cancer biology and tumor progression. A number of transcription factors involved in tumor cell EMT and microRNA-regulated EMT have been reported. This review discussed recent findings and new players in EMT in gastrointestinal cancers. Since the molecular mechanisms of tumor progression are sometimes context-dependent, the recent findings of EMT have been reviewed in a context-dependent manner.

Key words: Epithelial-mesenchymal transition, gastrointestinal cancer, microRNA, transcription factor

\section{Introduction}

Epithielial-mesenchymal transition (EMT) is a well-known phenotype and essential for tumor invasion and metastasis. ${ }^{[1-3]}$ The phenotype change in EMT is drastic, so the theory has fascinated many investigators, and several mechanisms have been reported to date. However, the number of factors essential for EMT is increasing; thus, it is challenging to integrate those factors to understand their networking. In this review, we briefly updated the recent EMT findings in a context-dependent manner, because the mechanisms underlying a disease substantially depend on the original function of the affected organ. Theoretically, the concept of EMT explains various cancer characteristics including tumor cell invasion, metastasis, chemo resistance and stem cell phenotype; therefore, it has considerable clinical significance. Thus, this review explores both the molecular mechanism of EMT and its clinical significance.

Although many EMT players, such as transcription factors and microRNAs (miRNAs) have been introduced so far such as transcription factors and miRNAs, their roles are to some extent-dependent on the context. Therefore, we discussed the role of each molecule in a context-dependent manner to clarify the specific role of each player.

\begin{tabular}{|l|l|}
\hline \multicolumn{2}{|c|}{ Access this article online } \\
\hline Quick Response Code: & Website: \\
\hline & www.jcmtjournal.com \\
\cline { 2 - 2 } & \\
\hline
\end{tabular}

\section{Esophageal Cancer}

Esophageal cancer (EC) has two distinct histological subtypes, that is, esophageal squamous cell carcinoma (ESCC) and esophageal adenocarcinoma (EAC). ${ }^{[4]}$ The former commonly occurs in Asia, whereas the latter is common in the United States and Western countries. Transforming growth factor- $\beta 1$ (TGF- $\beta 1$ ) was reported to induce EMT in EAC via the mothers against decapentaplegic homolog (SMAD) 4 pathway and this signaling was inhibited by bone morphogenetic protein 7 , another member of the TGF- $\beta 1$ superfamily. ${ }^{[5]}$ Using immortalized esophageal keratinocyte, TGF- $\beta 1$ was shown to regulate mitochondrial superoxide dismutase 2 (SOD2) which possesses antioxidant activity, to convert $\mathrm{CD} 44_{\text {low }}$ to $\mathrm{CD} 44_{\text {high }}$ cells. Expression of SOD2 was transcriptionally regulated by $N F-\kappa B$ and zinc finger E-box binding homeobox 2 (ZEB2), but not $\mathrm{ZEB} 1 .^{[6]}$ In the same cells, it was also reported that TGF- $\beta 1$-mediated EMT required p53 mutation accompanied by up-regulation of ZEB1 and the loss of epithelial growth factor receptor (EGFR)-dependent

This is an open access article distributed under the terms of the Creative Commons Attribution-NonCommercial-ShareAlike 3.0 License, which allows others to remix, tweak, and build upon the work non-commercially, as long as the author is credited and the new creations are licensed under the identical terms.

\section{For reprints contact: reprints@ medknow.com}

How to cite this article: Okabe $\mathrm{H}$, Mima K, Saito $\mathrm{S}$, Hayashi $\mathrm{H}$, Imai K, Nitta H, Hashimoto D, Chikamoto A, Ishiko T, Beppu T, Baba H. Epithelial-mesenchymal transition in gastroenterological cancer. $\mathrm{J}$ Cancer Metastasis Treat 2015;1:183-9.

Received: 27-07-2015; Accepted: 12-08-2015. 
senescence program. ${ }^{[7]}$ Epithelial cell adhesion molecule (EpCAM), a well-known marker for circulating tumor cells in many solid tumors, is down-regulated in TGF- $\beta 1$-mediated EMT. However, EpCAM expression in disseminated tumor cells (DTCs) was associated with lymph node metastasis and decreased overall survival of patients with EC. The conflicting evidence that DTCs need the process of EMT but express epithelial cell marker EpCAM is supported by the result that high expression of EpCAM promoted tumor outgrowth after xenotransplantation of esophageal carcinoma cells, suggesting that EpCAM expression changes dynamically over the course during cancer progression. ${ }^{[8]}$

A notable EMT inducer that has recently been reported is interleukin-23 (IL-23). IL-23 is mainly produced by Th17 cells that infiltrate in the tumor microenvironment and contributes to EMT via activation of the Wnt/ $\beta$-catenin pathway in esophageal squamous carcinoma. ${ }^{[9]}$ Eukaryotic initiation factor 5A2 (eIF5A2) was first isolated as an oncoprotein and was later found to be involved in EMT. Increased expression of eIF5A2 induced ESCC metastasis and angiogenesis via the hypoxia inducible factor-1 signaling pathway in esophageal squamous cell lines. ${ }^{[10]}$ The clinical investigation revealed Snail overexpression in $40 \%$ of patients with SCC tissue samples, which was associated with vascular invasion, advanced clinical stage and the EMT phenotype. ${ }^{[1]}$

\section{Gastric Cancer}

Distinct carcinogenetic pathways have been reported for intestinal and diffuse type gastric carcinoma, but EMT has been mainly discussed for the latter phenotype. ${ }^{[12]}$ The link between EMT and gastric adenocarcinoma could be partly because of the $H$. pylori cytotoxin-associated gene A (CagA) oncoprotein, which is responsible for the "hummingbird" phenotype in vitro, which mimics EMT. ${ }^{[13]}$ CagA overexpression in gastric cancer (GC) cells up-regulated the expression of mesenchymal markers and CD44, which is a cancer stem cell marker in GC. ${ }^{[14]}$ CagA overexpressing cancer cells also showed high tumorigenic ability in vivo. Immunohistochemical analysis of samples from individuals with $H$. pylori infection confirmed high CD44 expression and expression of different mesenchymal markers. ${ }^{[15]}$ Tissue microarray analysis of samples from $385 \mathrm{GC}$ patients revealed three miRNAs (miR-200c, miR-200b and miR-125b) to be significantly associated with survival. Functional experiments in a mouse model demonstrated that miR-200b suppressed ZEB1 and E-cadherin and inhibited cell migration and tumor growth. ${ }^{[16]}$ In vitro analysis revealed that overexpression of miR-200b also down-regulated ZEB2 expression, which in turn significantly reduced cellular proliferation, migration and invasion in GC cells. ${ }^{[17]} \mathrm{miR}-7$, which is down-regulated in highly metastatic GC cell lines, was found to be involved in metastasis by regulating its direct target, insulin-like growth factor-1 receptor. Overexpression of miR-7 was able to suppress Snail expression, increase E-cadherin expression and partially reverse EMT. ${ }^{[18]}$ Several other EMT inducers have been reported recently. For example, erythropoietin-producing hepatocellular (Eph) A2 overexpression resulted in up-regulation of the EMT markers N-cadherin and Snail, and the Wnt/ $\beta$-catenin targets TCF4, Cyclin-D1 and c-Myc. In contrast, Eph A2 silence by short hairpin RNA had the opposite effect. ${ }^{[19]}$ SALL4, a zinc-finger transcriptional factor for embryonic stem cell's self-renewal and pluripotency, has been suggested to be involved in tumorigenesis. SALL4 overexpression induced EMT with increased expression of Twist1 and N-cadherin, and decreased expression of E-cadherin. ${ }^{[20]}$ Telomerase activation through induction of human telomerase reverse transcriptase (hTERT) induced malignant transformation by stabilizing telomeres. hTERT overexpression could promote EMT and stemness of GC cells. TGF- $\beta 1$ and $\beta$-catenin-mediated EMT was abolished by depletion of hTERT. ${ }^{[21]}$ In the gastric epithelium, the runt domain transcription factor RUNX3 functions as a key mediator of the TGF- $\beta$ pathway. Loss of RUNX3 in gastric epithelial cells results in EMT and production of tumorigenic stem cell-like subpopulation expressing gastric stem cell marker Lgr5. Loss of both RUNX3 and p53 caused gastric epithelial cells to be sensitized to TGF- $\beta$-induced EMT, during which the resultant induction of Lgr5 is enhanced by aberrantly activated Wnt pathway. ${ }^{[22]}$

\section{Colorectal Cancer}

EMT is critical in transdifferentiation of polarized epithelial cells to an invasive mesenchymal phenotype. The function of EMT transcription factors in colorectal cancer (CRC) has been reported. Snail, an activator of EMT, was expressed at high levels in CRC colonospheres. Overexpression of Snail in CRC cells induced colonosphere-forming property and cell dedifferentiation. Blocking IL-8 expression or activity disrupted the Snail-induced stem cell-like features of colonospheres. ${ }^{[23]}$ Snail directly induced zinc finger protein 281 (ZNF281) transcription and repressed miR-34a/b/c, thereby protection of ZNF281 mRNA from direct down-regulation by miR-34. Furthermore, p53 activation resulted in miR-34a-dependent repression of ZNF81. ${ }^{[24]}$ Syngeneic Twist1-positive colon carcinoma cells (CT26) that invaded tissues surrounding tumors demonstrated the mesenchymal phenotype. ${ }^{[25]}$ Genotype also affected the mechanism of EMT. TGF- $\beta 1$ induced changes in cell morphology, gene expression, motility and invasion consistent with EMT in microsatellite stable colon cancer cells, whereas cells exhibited 
IL-6-dependent activation of signal transducer and activator of transcription 3 (STAT3), a conserved and direct target of miR-34a. ${ }^{[26]}$ Stimulation of EMT results in the nuclear translocation of pyruvate kinase M2 (PKM2) in colon cancer cells. EMT stimulation causes direct interaction of PKM2 in the nucleus with TGF- $\beta$-induced factor homeobox 2, a transcriptional cofactor repressor of TGF- $\beta$ signaling. ${ }^{[27]}$ The roles of miRNA in EMT in CRC have been reported. For example, liver metastatic tissues showed higher expression of miR-200c than that of the primary tumor, and miR-200c overexpression was significantly associated with hypomethylation of the miR-200c promoter. ${ }^{[28]}$ Overexpression of miR-212 inhibited CRC cell migration and invasion in vitro and intrahepatic and pulmonary metastasis in vivo. Manganese SOD (MnSOD) was identified as a direct target of miR-212, and an inverse correlation has been observed between the level of miR-212 and MnSOD protein in colorectal tumor samples. MnSOD was required for down-regulation of epithelial markers and up-regulation of mesenchymal markers in CRC cells. ${ }^{[29]}$

\section{Hepatocellular Carcinoma}

TGF- $\beta$ is a major microenvironmental factor to affect hepatocellular carcinoma (HCC) dedifferentiation, inducing EMT and acquisition of metastatic phenotypes. Transcriptomic analysis on human HCC tissue samples revealed that TGF- $\beta$ signaling was activated in a subpopulation of HCC, called Wnt-TGF- $\beta$ subclass. ${ }^{[30,31]}$ Sequential transcriptome analysis suggested that TGF- $\beta$ signaling was a late event accompanied with extensive gene alterations. ${ }^{[32]}$ TGF- $\beta$ has been shown to induce hepatocyte nuclear factor- $4 \alpha(\mathrm{HNF}-4 \alpha)$ post-translational modifications that correlate with the early loss of the ability of HNF- $4 \alpha$ to bind to target gene promoters via glycogen synthase kinase-3 $\beta$ (GSK-3 $\beta$ ) kinase during EMT. ${ }^{[33]}$ The receptor tyrosine kinase Axl binds to $14-3-3 \zeta$ as a result of phosphorylation of the linker region of SMAD3 at Ser213, which causes the up-regulation of TGF- $\beta$ target genes such as PAI1, MMP9 and Snail. ${ }^{[34]}$ The function of EMT transcription factors have been updated recently. Accumulative data on non-coding RNA have revealed a novel mechanism of EMT in HCC. For example, miR-200c was down-regulated in $\mathrm{HCC}$ with bile duct tumor thrombus, which occurred in 30 out of 1,240 patients, and regulated ZEB1 expression as well as an invasive phenotype. ${ }^{[35]}$ The miR216a/217 cluster induced EMT and its direct targets, phosphatase and tensin homolog and SMAD7 were identified. ${ }^{[36]}$ miR-331-3p-mediated inhibition of $\mathrm{PH}$ domain and leucine-rich repeat protein phosphatase resulted in stimulation of protein kinase $\mathrm{B}$ (AKT) and subsequent EMT. ${ }^{[37]}$ miR-424-5p reversed resistance to anoikis, blocked EMT progression and inhibited its direct target ICAT/CTNNBIP1, a novel $\beta$-catenin-interacting protein. ${ }^{[38]} \mathrm{A}$ non-coding antisense transcript, ZEB1-antisense1 (ZEB1-AS1), promoted
EMT and metastasis in HCC. The zeb1-as1 promoter was hypomethylated in human HCC samples and resulted in tumor specific up-regulation of ZEB1-AS1. ${ }^{[39]}$ IncRNA-AL589182.3 (ENST00000493038), which can be activated by TGF- $\beta$, up-regulated ZEB1 and ZEB2 through competitively binding to the miR-200 family and induced tumor cell EMT and invasion. ${ }^{[40]}$ Interestingly, hepatitis $\mathrm{C}$ virus (HCV) has also been found to contribute to EMT. HCV core protein down-regulated secreted frizzled-related protein 1 (SFRP1) expression by inducing hypermethylation of the SFRP1 promoter $^{[41]}$ A previous transgenic mouse study demonstrated that overexpression of HCV core protein in HCC cells increased active TGF- $\beta$ levels in culture supernatants and induced SMAD2/3 phosphorylation. HCC cells expressing HCV core protein could activate stellate cells in co-culture and this activation was TGF- $\beta$-dependent. ${ }^{[42]} \mathrm{CD} 44 \mathrm{~s}$, a known cancer stem cell marker in many malignancies, mediated TGF- $\beta$-induced EMT, and regulated mesenchymal phenotype in HCC. ${ }^{[43,44]}$

\section{Cholangiocarcinoma}

Since this disease is not common, clinical and basic research on human cholangiocarcinoma (CCA) samples is limited. CCA is one of the solid cancers that have no effective molecular targeted therapy to date. Gemcitabine plus platinum is the only chemotherapeutic drug that to some extent inhibits CCA progression. ${ }^{[45]}$ Several EMT-related molecules are also known to play pivotal roles in CCA. Inactivation of miR-200c is reported to induce the expression of mesenchymal markers and NCAM1, a known hepatic stem/progenitor cell marker. ${ }^{[46]}$ STAT3-driven expression of small proline-rich protein 2a suppressed the interaction of miR-200c/141 with ZEB1. ${ }^{[4]}$ Although the efficacy of the EGFR tyrosine kinase inhibitors, erlotinib and cetuximab, has not been confirmed in CCA treatment, ${ }^{[48]}$ activation of the EGF-EGFR axis is known to abolish gefitinib-mediated EMT progression. ${ }^{[49]}$ ANXA8 was found to be involved in EGF-forkhead box protein $\mathrm{O}$ signaling-mediated EMT progression. ${ }^{[50]}$ The sonic hedgehog ligand is highly expressed in human CCA, and treatment with the hedgehog inhibitors, cyclopamine and 5E1, suppressed cell proliferation, migration and invasion by down-regulating the target genes hepatoblastoma 1 and 2. Furthermore, these inhibitors have been shown to attenuate EMT. ${ }^{[1]}$ In addition to the above-mentioned molecules, some unique molecules have also been linked to EMT recently in CCA, which include 4 histamines (H1-H4) and their receptor (HR). Loss of $\mathrm{H} 3 \mathrm{HR}$ expression or overexpression of H4HR has been shown to significantly decrease CCA proliferation and disrupt EMT progression. ${ }^{[52]}$

\section{Pancreatic Cancer}

Pancreatic cancer is one of the worst solid cancers in terms of prognosis and treatment outcome, because there is no promising molecular target identified to 
date. EMT was first reported in this malignancy two decades ago, and the major functional interactions of the EMT-transcription factors have also been reported. The genomic landscape of pancreatic cancer has been partially unveiled. ${ }^{[53]}$ However, the role of each key molecule involved in EMT remains to be elucidated, an effective therapeutic molecular target is yet to be identified for pancreatic cancer. The epigenetic analysis revealed that the Class I histone deacetylase inhibitor mocetinostat suppresses ZEB1 and induces miR-203 re-expression, thus, leading to the repression of stemness properties and drug resistance. ${ }^{[54]}$ TGF- $\beta 1$ was highly up-regulated in pancreatic cancer. ${ }^{[55]}$ TGF- $\beta 1$ has been shown to induce EMT, SMAD2/3 phosphorylation, restoration of retinoblastoma 1 expression and SMAD-dependent up-regulation of Wnt7b in KRC cell line. In in vivo orthotopic models, inhibition of TGF- $\beta 1$ signaling suppressed those effects, resulting in tumor regression and decrease in metastasis. ${ }^{[56]}$ The calcium-/calcineurin-responsive nuclear factor of activated $\mathrm{T}$ cells, a transcription factor expressed during inflammation, drives EMT in a sex determining region-box 2-dependent manner and loss of p53 induced EMT, and acquisition of cancer stem cell-like properties by down-regulating miR-200c. ${ }^{[57]}$ Ataxia telangiectasia Group D complementing gene, which is highly expressed in pancreatic cancer, ${ }^{[58]}$ up-regulated CD44 in mouse and human PanIN lesions via activation of $\beta$-catenin signaling. This in turn results in the induction of EMT phenotype and expression of ZEB1 and Snail1. ${ }^{[59]}$

\section{Perspectives}

Increasing evidence supports the role of EMT in cancer progression, metastasis and drug resistance. Recent studies of EMT transcription factors and microRNAs are shown in Tables 1 and 2 respectively. In a tumorigenic mouse model, it was shown that EMT precedes pancreatic tumor formation. ${ }^{[60]}$ However, whether EMT occurs in the early stage or late stage of tumor formation remains to be confirmed. The mesenchymal phenotype is essential for tumor cell migration and invasion. The epithelial phenotype might be required for cancer cells to spread to other organs. Cancer cells tend to acquire both phenotypes under specific conditions, and the functional aspect of each phenotype regarding chemoresistance remains elusive. ${ }^{[61]}$ EMT has been categorized into three types: developmental (Type I), fibrosis and wound healing (Type II), and cancer (Type III). Of these, Type III EMT is the least well understood. ${ }^{[62]}$ If Type III EMT can be classified further into subgroups based on the molecular mechanisms, it would be possible to develop personalized cancer therapeutic approaches based on the specific EMT stage.

\section{Financial support and sponsorship}

Nil.
Table 1: EMT TFs in gastroenterological malignancies

\begin{tabular}{lcccccc}
\hline TFs & EC & GC & CRC & HCC & PDCA & CCA \\
\hline ZEB1/2 & & {$[16,17]$} & {$[63]$} & {$[64]$} & {$[54]$} & \\
Twist1 & & & {$[25]$} & {$[65]$} & & \\
Snail & {$[11]$} & & {$[23,24,66]$} & {$[65]$} & & \\
SHP-1 & & & & {$[67]$} & \\
SMAD3/4 & {$[5]$} & & & & {$[56]$} \\
FoxC1 & & & & {$[68]$} & \\
FoxC2 & & {$[69]$} & & & \\
FoxM1 & & & & & {$[70,71]$} \\
FoxQ1 & & & & {$[72]$} & \\
NFATc1 & & & & & {$[57]$} & \\
\hline
\end{tabular}

EC: Esophageal carcinoma; GC: Gastric cancer; CRC: Colorectal cancer; HCC: Hepatocellular carcinoma; PDCA: Pancreatic ductal adenocarcinoma; CCA: Cholangiocarcinoma; SMAD: Mothers against decapentaplegic homolog; ZEB1/2: Zinc finger E-box binding 1/2; TFs: Transcription factors; EMT: Epithelial-mesenchymal transition; NFATc1: Nuclear factor of activated T cells; SHP-1: Small heterodimer partner-1

Table 2: MicroRNA in gastroenterological malignancies

\begin{tabular}{|c|c|c|c|c|c|c|}
\hline MicroRNA & Targets & EC & GC & CRC & $\mathrm{HCC}$ & PDCA CCA \\
\hline miR7 & IGF1R & & [18] & & & \\
\hline miR9 & CDH1 & [73] & & & & \\
\hline $\mathrm{miR} 34 \mathrm{a} / \mathrm{b} / \mathrm{c}$ & ZNF281 & & & [24] & & \\
\hline miR125b & SMAD2/4 & & & & & \\
\hline $\operatorname{miR} 130 b$ & IRF1 & & & & [74] & \\
\hline miR146a & Numb & & & [66] & & \\
\hline miR148a & Snail & & & & [75] & \\
\hline $\mathrm{miR} 200 \mathrm{~b} / \mathrm{c}$ & $\begin{array}{l}\text { ZEB1, } \\
\text { NCAM1 }\end{array}$ & & {$[16,17]$} & [28] & [35] & {$[76] \quad[46]$} \\
\hline $\operatorname{miR} 212$ & MnSOD & & & [29] & & \\
\hline $\mathrm{miR} 216 \mathrm{a} / 217$ & $\begin{array}{l}\text { PTEN/ } \\
\text { SMAD7 }\end{array}$ & & & & [36] & \\
\hline $\operatorname{miR} 223$ & Fbw7 & & & & & [77] \\
\hline $\operatorname{miR} 331-3 p$ & PHLPP & & & & [37] & \\
\hline $\operatorname{miR} 338-3 p$ & ZEB2 & & [78] & & & \\
\hline $\operatorname{miR} 424-5 p$ & $\begin{array}{l}\text { ICAT/ } \\
\text { CTNNBIP1 }\end{array}$ & & & & [38] & \\
\hline $\operatorname{miR} 655$ & ZEB1 & [79] & & & & \\
\hline lncRNA & ZEB1/2 & & & & [40] & \\
\hline
\end{tabular}

EC: Esophageal carcinoma; GC: Gastric cancer; CRC: Colorectal cancer; HCC: Hepatocellular carcinoma; PDCA: Pancreatic ductal adenocarcinoma; CCA: Cholangiocarcinoma; PHLPP: PH domain and leucine-rich repeat protein phosphatase; SMAD: Mothers against decapentaplegic homolog; PTEN: Phosphatase and tensin homolog; IGF1R: Insulin-like growth factor-1 receptor; ZNF281: Zinc finger protein 281; IRF1: Interferon regulatory factor 1; ZEB: Zinc finger E-box binding; NCAM1: Neural cell adhesion molecule; MnSOD: Manganese superoxide dismutase

\section{Conflicts of interest}

There are no conflicts of interest.

\section{References}

1. Tam WL, Weinberg RA. The epigenetics of epithelial-mesenchymal plasticity in cancer. Nat Med 2013;19:1438-49. 
2. Lee JM, Dedhar S, Kalluri R, Thompson EW. The epithelial-mesenchymal transition: new insights in signaling, development, and disease. $J$ Cell Biol 2006;172:973-81.

3. Thiery JP, Lim CT. Tumor dissemination: an EMT affair. Cancer Cell 2013;23:272-3.

4. Pennathur A, Gibson MK, Jobe BA, Luketich JD. Oesophageal carcinoma. Lancet 2013;381:400-12.

5. Rees JR, Onwuegbusi BA, Save VE, Alderson D, Fitzgerald RC. In vivo and in vitro evidence for transforming growth factor-beta1-mediated epithelial to mesenchymal transition in esophageal adenocarcinoma. Cancer Res 2006;66:9583-90.

6. Kinugasa H, Whelan KA, Tanaka K, Natsuizaka M, Long A, Guo A, Chang S, Kagawa S, Srinivasan S, Guha M, Yamamoto K, St Clair DK, Avadhani NG, Diehl JA, Nakagawa H. Mitochondrial SOD2 regulates epithelial-mesenchymal transition and cell populations defined by differential CD44 expression. Oncogene 2015; doi: 10.1038/onc.2014.449.

7. Ohashi S, Natsuizaka M, Wong GS, Michaylira CZ, Grugan KD, Stairs DB, Kalabis J, Vega ME, Kalman RA, Nakagawa M, Klein-Szanto AJ, Herlyn M, Diehl JA, Rustgi AK, Nakagawa H. Epidermal growth factor receptor and mutant p53 expand an esophageal cellular subpopulation capable of epithelial-to-mesenchymal transition through ZEB transcription factors. Cancer Res 2010;70:4174-84.

8. Driemel C, Kremling H, Schumacher S, Will D, Wolters J, Lindenlauf N, Mack B, Baldus SA, Hoya V, Pietsch JM, Panagiotidou P, Raba K, Vay C, Vallbohmer D, Harreus U, Knoefel WT, Stoecklein NH, Gires O. Context-dependent adaption of EpCAM expression in early systemic esophageal cancer. Oncogene 2014;33:4904-15.

9. Chen D, Li W, Liu S, Su Y, Han G, Xu C, Liu H, Zheng $\mathrm{T}$, Zhou $\mathrm{Y}$, Mao $\mathrm{C}$. Interleukin-23 promotes the epithelial-mesenchymal transition of oesophageal carcinoma cells via the Wnt/beta-catenin pathway. Sci Rep 2015;5:8604.

10. Li Y, Fu L, Li JB, Qin Y, Zeng TT, Zhou J, Zeng ZL, Chen J, Cao TT, Ban X, Qian C, Cai Z, Xie D, Huang P, Guan XY. Increased expression of EIF5A2, via hypoxia or gene amplification, contributes to metastasis and angiogenesis of esophageal squamous cell carcinoma. Gastroenterology 2014;146:1701-13.e9.

11. Usami Y, Satake S, Nakayama F, Matsumoto M, Ohnuma K, Komori T, Semba S, Ito A, Yokozaki H. Snail-associated epithelial-mesenchymal transition promotes oesophageal squamous cell carcinoma motility and progression. $J$ Pathol 2008;215:330-9.

12. Rosivatz E, Becker I, Specht K, Fricke E, Luber B, Busch R, Hofler H, Becker KF. Differential expression of the epithelial-mesenchymal transition regulators snail, SIP1, and twist in gastric cancer. Am J Pathol 2002;161:1881-91.

13. Amieva MR, Vogelmann R, Covacci A, Tompkins LS, Nelson WJ, Falkow S. Disruption of the epithelial apical-junctional complex by Helicobacter pylori CagA. Science 2003;300:1430-4.

14. Takaishi S, Okumura T, Tu S, Wang SS, Shibata W, Vigneshwaran R, Gordon SA, Shimada Y, Wang TC. Identification of gastric cancer stem cells using the cell surface marker CD44. Stem Cells 2009;27:1006-20.

15. Bessede E, Dubus P, Megraud F, Varon C. Helicobacter pylori infection and stem cells at the origin of gastric cancer. Oncogene 2015;34:2547-55.

16. Song F, Yang D, Liu B, Guo Y, Zheng H, Li L, Wang T, Yu J, Zhao Y, Niu R, Liang H, Winkler H, Zhang W, Hao X, Chen K. Integrated microRNA network analyses identify a poor-prognosis subtype of gastric cancer characterized by the miR-200 family. Clin Cancer Res 2014;20:878-89.
17. Kurashige J, Kamohara H, Watanabe M, Hiyoshi Y, Iwatsuki M, Tanaka Y, Kinoshita K, Saito S, Baba Y, Baba H. MicroRNA-200b regulates cell proliferation, invasion, and migration by directly targeting ZEB2 in gastric carcinoma. Ann Surg Oncol 2012;19 Suppl 3:S656-64.

18. Zhao X, Dou W, He L, Liang S, Tie J, Liu C, Li T, Lu Y, Mo P, Shi Y, Wu K, Nie Y, Fan D. MicroRNA-7 functions as an anti-metastatic microRNA in gastric cancer by targeting insulin-like growth factor-1 receptor. Oncogene 2013;32:1363-72.

19. Huang J, Xiao D, Li G, Ma J, Chen P, Yuan W, Hou F, Ge J, Zhong M, Tang Y, Xia X, Chen Z. EphA2 promotes epithelial-mesenchymal transition through the Wnt/beta-catenin pathway in gastric cancer cells. Oncogene 2014;33:2737-47.

20. Zhang L, Xu Z, Xu X, Zhang B, Wu H, Wang M, Zhang X, Yang T, Cai J, Yan Y, Mao F, Zhu W, Shao Q, Qian H, Xu W. SALL4, a novel marker for human gastric carcinogenesis and metastasis. Oncogene 2014;33:5491-500.

21. Liu Z, Li Q, Li K, Chen L, Li W, Hou M, Liu T, Yang J, Lindvall C, Bjorkholm M, Jia J, Xu D. Telomerase reverse transcriptase promotes epithelial-mesenchymal transition and stem cell-like traits in cancer cells. Oncogene 2013;32:4203-13.

22. Voon DC, Wang H, Koo JK, Nguyen TA, Hor YT, Chu YS, Ito K, Fukamachi $\mathrm{H}$, Chan SL, Thiery JP, Ito Y. Runx3 protects gastric epithelial cells against epithelial-mesenchymal transition-induced cellular plasticity and tumorigenicity. Stem Cells 2012;30:2088-99.

23. Hwang WL, Yang MH, Tsai ML, Lan HY, Su SH, Chang SC, Teng HW, Yang SH, Lan YT, Chiou SH, Wang HW. SNAIL regulates interleukin-8 expression, stem cell-like activity, and tumorigenicity of human colorectal carcinoma cells. Gastroenterology 2011;141:279-91, 291.e1-5.

24. Hahn S, Jackstadt R, Siemens H, Hunten S, Hermeking H. SNAIL and miR-34a feed-forward regulation of ZNF281/ZBP99 promotes epithelial-mesenchymal transition. EMBO J 2013;32:3079-95.

25. Celesti G, Di Caro G, Bianchi P, Grizzi F, Basso G, Marchesi F, Doni A, Marra G, Roncalli M, Mantovani A, Malesci A, Laghi L. Presence of Twist1-positive neoplastic cells in the stroma of chromosome-unstable colorectal tumors. Gastroenterology 2013;145:647-57.e15.

26. Rokavec $\mathrm{M}$, Oner MG, Li H, Jackstadt R, Jiang L, Lodygin D, Kaller M, Horst D, Ziegler PK, Schwitalla S, Slotta-Huspenina J, Bader FG, Greten FR, Hermeking H. IL-6R/STAT3/miR-34a feedback loop promotes EMT-mediated colorectal cancer invasion and metastasis. $J$ Clin Invest 2014;124:1853-67.

27. Hamabe A, Konno M, Tanuma N, Shima H, Tsunekuni K, Kawamoto K, Nishida N, Koseki J, Mimori K, Gotoh N, Yamamoto H, Doki Y, Mori M, Ishii H. Role of pyruvate kinase M2 in transcriptional regulation leading to epithelial-mesenchymal transition. Proc Natl Acad Sci U S A 2014;111:15526-31.

28. Hur K, Toiyama Y, Takahashi M, Balaguer F, Nagasaka T, Koike J, Hemmi H, Koi M, Boland CR, Goel A. MicroRNA-200c modulates epithelial-to-mesenchymal transition (EMT) in human colorectal cancer metastasis. Gut 2013;62:1315-26.

29. Meng $X$, Wu J, Pan $C$, Wang $H$, Ying $X$, Zhou $Y$, Yu H, Zuo Y, Pan Z, Liu RY, Huang W. Genetic and epigenetic down-regulation of microRNA-212 promotes colorectal tumor metastasis via dysregulation of MnSOD. Gastroenterology 2013;145:426-36.e1-6.

30. Hoshida Y, Moeini A, Alsinet C, Kojima K, Villanueva A. 
Gene signatures in the management of hepatocellular carcinoma. Semin Oncol 2012;39:473-85.

31. Lachenmayer A, Alsinet C, Savic R, Cabellos L, Toffanin S, Hoshida Y, Villanueva A, Minguez B, Newell P, Tsai HW, Barretina J, Thung S, Ward SC, Bruix J, Mazzaferro V, Schwartz M, Friedman SL, Llovet JM. Wnt-pathway activation in two molecular classes of hepatocellular carcinoma and experimental modulation by sorafenib. Clin Cancer Res 2012;18:4997-5007.

32. Marquardt JU, Seo D, Andersen JB, Gillen MC, Kim MS, Conner EA, Galle PR, Factor VM, Park YN, Thorgeirsson SS. Sequential transcriptome analysis of human liver cancer indicates late stage acquisition of malignant traits. $J$ Hepatol 2014;60:346-53.

33. Cozzolino AM, Alonzi T, Santangelo L, Mancone C, Conti B, Steindler C, Musone M, Cicchini C, Tripodi M, Marchetti A. TGFbeta overrides HNF4alpha tumor suppressing activity through GSK3beta inactivation: implication for hepatocellular carcinoma gene therapy. J Hepatol 2013;58:65-72.

34. Reichl P, Dengler M, van Zijl F, Huber H, Fuhrlinger G, Reichel C, Sieghart W, Peck-Radosavljevic M, Grubinger M, Mikulits W. Axl activates autocrine transforming growth factor-beta signaling in hepatocellular carcinoma. Hepatology 2015;61:930-41.

35. Yeh TS, Wang F, Chen TC, Yeh CN, Yu MC, Jan YY, Chen MF. Expression profile of microRNA-200 family in hepatocellular carcinoma with bile duct tumor thrombus. Ann Surg 2014;259:346-54.

36. Xia H, Ooi LL, Hui KM. MicroRNA-216a/217-induced epithelial-mesenchymal transition targets PTEN and SMAD7 to promote drug resistance and recurrence of liver cancer. Hepatology 2013;58:629-41.

37. Chang RM, Yang $\mathrm{H}$, Fang $\mathrm{F}$, $\mathrm{Xu}$ JF, Yang LY. MicroRNA-331-3p promotes proliferation and metastasis of hepatocellular carcinoma by targeting $\mathrm{PH}$ domain and leucine-rich repeat protein phosphatase. Hepatology 2014;60:1251-63.

38. Zhang Y, Li T, Guo P, Kang J, Wei Q, Jia X, Zhao W, Huai W, Qiu Y, Sun L, Han L. MiR-424-5p reversed epithelial-mesenchymal transition of anchorage-independent HCC cells by directly targeting ICAT and suppressed HCC progression. Sci Rep 2014;4:6248.

39. Li T, Xie J, Shen C, Cheng D, Shi Y, Wu Z, Deng X, Chen H, Shen B, Peng C, Li H, Zhan Q, Zhu Z. Upregulation of long noncoding RNA ZEB1-AS1 promotes tumor metastasis and predicts poor prognosis in hepatocellular carcinoma. Oncogene 2015; doi: 10.1038/onc.2015.223

40. Yuan JH, Yang F, Wang F, Ma JZ, Guo YJ, Tao QF, Liu F, Pan W, Wang TT, Zhou CC, Wang SB, Wang YZ, Yang Y, Yang N, Zhou WP, Yang GS, Sun SH. A long noncoding RNA activated by TGF-beta promotes the invasion-metastasis cascade in hepatocellular carcinoma. Cancer Cell 2014;25:666-81

41. Quan H, Zhou F, Nie D, Chen Q, Cai X, Shan X, Zhou Z, Chen K, Huang A, Li S, Tang N. Hepatitis C virus core protein epigenetically silences SFRP1 and enhances HCC aggressiveness by inducing epithelial-mesenchymal transition. Oncogene 2014;33:2826-35.

42. Benzoubir N, Lejamtel C, Battaglia S, Testoni B, Benassi B, Gondeau C, Perrin-Cocon L, Desterke C, Thiers V, Samuel D, Levrero M, Brechot C, Bourgeade MF. HCV core-mediated activation of latent TGF-beta via thrombospondin drives the crosstalk between hepatocytes and stromal environment. J Hepatol 2013;59:1160-8.

43. Okabe $H$, Ishimoto $T$, Mima $K$, Nakagawa S, Hayashi $H$,
Kuroki H, Imai K, Nitta H, Saito S, Hashimoto D, Chikamoto A, Ishiko T, Watanabe M, Nagano O, Beppu T, Saya H, Baba H. CD44s signals the acquisition of the mesenchymal phenotype required for anchorage-independent cell survival in hepatocellular carcinoma. $\mathrm{Br} J$ Cancer 2014;110:958-66

44. Mima K, Okabe $\mathrm{H}$, Ishimoto $\mathrm{T}$, Hayashi $\mathrm{H}$, Nakagawa $\mathrm{S}$, Kuroki H, Watanabe M, Beppu T, Tamada M, Nagano O, Saya H, Baba H. CD44s regulates the TGF-beta-mediated mesenchymal phenotype and is associated with poor prognosis in patients with hepatocellular carcinoma. Cancer Res 2012;72:3414-23

45. Valle J, Wasan H, Palmer DH, Cunningham D, Anthoney A, Maraveyas A, Madhusudan S, Iveson T, Hughes S, Pereira SP, Roughton M, Bridgewater J, Investigators ABCT. Cisplatin plus gemcitabine versus gemcitabine for biliary tract cancer. N Engl J Med 2010;362:1273-81.

46. Oishi N, Kumar MR, Roessler S, Ji J, Forgues M, Budhu A, Zhao X, Andersen JB, Ye QH, Jia HL, Qin LX, Yamashita T, Woo HG, Kim YJ, Kaneko S, Tang ZY, Thorgeirsson SS, Wang XW. Transcriptomic profiling reveals hepatic stem-like gene signatures and interplay of miR-200c and epithelial-mesenchymal transition in intrahepatic cholangiocarcinoma. Hepatology 2012;56:1792-803.

47. Mizuguchi Y, Isse K, Specht S, Lunz JG 3rd, Corbitt N, Takizawa T, Demetris AJ. Small proline rich protein $2 \mathrm{a}$ in benign and malignant liver disease. Hepatology 2014;59:1130-43.

48. Malka D, Cervera $\mathrm{P}$, Foulon $\mathrm{S}$, Trarbach $\mathrm{T}$, de la Fouchardiere C, Boucher E, Fartoux L, Faivre S, Blanc JF, Viret F, Assenat E, Seufferlein T, Herrmann T, Grenier J, Hammel P, Dollinger M, Andre T, Hahn P, Heinemann V, Rousseau V, Ducreux M, Pignon JP, Wendum D, Rosmorduc O, Greten TF, investigators B. Gemcitabine and oxaliplatin with or without cetuximab in advanced biliary-tract cancer (BINGO): a randomised, open-label, non-comparative phase 2 trial. Lancet Oncol 2014;15:819-28.

49. Claperon A, Mergey M, Nguyen Ho-Bouldoires TH, Vignjevic D, Wendum D, Chretien Y, Merabtene F, Frazao A, Paradis V, Housset C, Guedj N, Fouassier L. EGF/EGFR axis contributes to the progression of cholangiocarcinoma through the induction of an epithelial-mesenchymal transition. $J$ Hepatol 2014;61:325-32.

50. Lee MJ, Yu GR, Yoo HJ, Kim JH, Yoon BI, Choi YK, Kim DG. ANXA8 down-regulation by EGF-FOXO4 signaling is involved in cell scattering and tumor metastasis of cholangiocarcinoma. Gastroenterology 2009;137:1138-50, 50.e1-9.

51. El Khatib M, Kalnytska A, Palagani V, Kossatz U, Manns MP, Malek NP, Wilkens L, Plentz RR. Inhibition of hedgehog signaling attenuates carcinogenesis in vitro and increases necrosis of cholangiocellular carcinoma. Hepatology 2013;57:1035-45.

52. Meng F, Han Y, Staloch D, Francis T, Stokes A, Francis H. The H4 histamine receptor agonist, clobenpropit, suppresses human cholangiocarcinoma progression by disruption of epithelial mesenchymal transition and tumor metastasis. Hepatology 2011;54:1718-28.

53. Jones S, Zhang X, Parsons DW, Lin JC, Leary RJ, Angenendt P, Mankoo P, Carter H, Kamiyama H, Jimeno A, Hong SM, Fu B, Lin MT, Calhoun ES, Kamiyama M, Walter K, Nikolskaya T, Nikolsky Y, Hartigan J, Smith DR, Hidalgo M, Leach SD, Klein AP, Jaffee EM, Goggins M, Maitra A, Iacobuzio-Donahue C, Eshleman JR, Kern SE, Hruban RH, Karchin R, Papadopoulos N, Parmigiani G, 
Vogelstein B, Velculescu VE, Kinzler KW. Core signaling pathways in human pancreatic cancers revealed by global genomic analyses. Science 2008;321:1801-6.

54. Meidhof S, Brabletz S, Lehmann W, Preca BT, Mock K, Ruh M, Schuler J, Berthold M, Weber A, Burk U, Lubbert M, Puhr M, Culig Z, Wellner U, Keck T, Bronsert P, Kusters S, Hopt UT, Stemmler MP, Brabletz T. ZEB1-associated drug resistance in cancer cells is reversed by the class I HDAC inhibitor mocetinostat. EMBO Mol Med 2015;7:831-47.

55. Friess H, Yamanaka Y, Buchler M, Ebert M, Beger HG, Gold LI, Korc M. Enhanced expression of transforming growth factor beta isoforms in pancreatic cancer correlates with decreased survival. Gastroenterology 1993;105:1846-56.

56. Gore AJ, Deitz SL, Palam LR, Craven KE, Korc M. Pancreatic cancer-associated retinoblastoma 1 dysfunction enables TGF-beta to promote proliferation. $J$ Clin Invest 2014;124:338-52.

57. Singh SK, Chen NM, Hessmann E, Siveke J, Lahmann M, Singh G, Voelker N, Vogt S, Esposito I, Schmidt A, Brendel C, Stiewe T, Gaedcke J, Mernberger M, Crawford HC, Bamlet WR, Zhang JS, Li XK, Smyrk TC, Billadeau DD, Hebrok M, Neesse A, Koenig A, Ellenrieder V. Antithetical NFATc1-Sox2 and p53-miR200 signaling networks govern pancreatic cancer cell plasticity. EMBO J 2015;34:517-30.

58. Logsdon CD, Simeone DM, Binkley C, Arumugam T, Greenson JK, Giordano TJ, Misek DE, Kuick R, Hanash S. Molecular profiling of pancreatic adenocarcinoma and chronic pancreatitis identifies multiple genes differentially regulated in pancreatic cancer. Cancer Res 2003;63:2649-57.

59. Wang L, Yang H, Abel EV, Ney GM, Palmbos PL, Bednar F, Zhang Y, Leflein J, Waghray M, Owens S, Wilkinson JE, Prasad J, Ljungman M, Rhim AD, Pasca di Magliano M, Simeone DM. ATDC induces an invasive switch in KRAS-induced pancreatic tumorigenesis. Genes Dev 2015;29:171-83.

60. Rhim AD, Mirek ET, Aiello NM, Maitra A, Bailey JM, McAllister F, Reichert M, Beatty GL, Rustgi AK, Vonderheide RH, Leach SD, Stanger BZ. EMT and dissemination precede pancreatic tumor formation. Cell 2012;148:349-61.

61. Yu M, Bardia A, Wittner BS, Stott SL, Smas ME, Ting DT, Isakoff SJ, Ciciliano JC, Wells MN, Shah AM, Concannon KF, Donaldson MC, Sequist LV, Brachtel E, Sgroi D, Baselga J, Ramaswamy S, Toner M, Haber DA, Maheswaran S. Circulating breast tumor cells exhibit dynamic changes in epithelial and mesenchymal composition. Science 2013;339:580-4

62. Kalluri R, Weinberg RA. The basics of epithelial-mesenchymal transition. J Clin Invest 2009;119:1420-8.

63. Kahlert C, Lahes S, Radhakrishnan P, Dutta S, Mogler C, Herpel E, Brand K, Steinert G, Schneider M, Mollenhauer M, Reissfelder C, Klupp F, Fritzmann J, Wunder C, Benner A, Kloor M, Huth C, Contin P, Ulrich A, Koch M, Weitz J. Overexpression of ZEB2 at the invasion front of colorectal cancer is an independent prognostic marker and regulates tumor invasion in vitro. Clin Cancer Res 2011;17:7654-63.

64. Zeng S, Xiao YF, Tang B, Hu CJ, Xie R, Yang SM, Li BS. Long noncoding RNA in digestive tract cancers: function, mechanism, and potential biomarker. Oncologist 2015;20:898-906.

65. Yang $\mathrm{MH}$, Chen $\mathrm{CL}$, Chau GY, Chiou SH, Su CW, Chou TY, Peng WL, Wu JC. Comprehensive analysis of the independent effect of twist and snail in promoting metastasis of hepatocellular carcinoma. Hepatology 2009;50:1464-74.

66. Hwang WL, Jiang JK, Yang SH, Huang TS, Lan HY, Teng HW, Yang CY, Tsai YP, Lin CH, Wang HW, Yang MH. MicroRNA-146a directs the symmetric division of Snail-dominant colorectal cancer stem cells. Nat Cell Biol 2014;16:268-80.

67. Fan LC, Shiau CW, Tai WT, Hung MH, Chu PY, Hsieh FS, Lin $\mathrm{H}, \mathrm{Yu} \mathrm{HC}$, Chen KF. SHP-1 is a negative regulator of epithelial-mesenchymal transition in hepatocellular carcinoma. Oncogene 2015; doi: 10.1038/onc.2015.223.

68. Xia L, Huang W, Tian D, Zhu H, Qi X, Chen Z, Zhang Y, $\mathrm{Hu}$ H, Fan D, Nie Y, Wu K. Overexpression of forkhead box $\mathrm{C} 1$ promotes tumor metastasis and indicates poor prognosis in hepatocellular carcinoma. Hepatology 2013;57:610-24.

69. Ren YH, Liu KJ, Wang M, Yu YN, Yang K, Chen Q, Yu B, Wang W, Li QW, Wang J, Hou ZY, Fang JY, Yeh ET, Yang J, Yi J. De-SUMOylation of FOXC2 by SENP3 promotes the epithelial-mesenchymal transition in gastric cancer cells. Oncotarget 2014;5:7093-104.

70. Huang C, Qiu Z, Wang L, Peng Z, Jia Z, Logsdon CD, Le X, Wei D, Huang S, Xie K. A novel FoxM1-caveolin signaling pathway promotes pancreatic cancer invasion and metastasis. Cancer Res 2012;72:655-65.

71. Huang C, Xie D, Cui J, Li Q, Gao Y, Xie K. FOXM1c promotes pancreatic cancer epithelial-to-mesenchymal transition and metastasis via upregulation of expression of the urokinase plasminogen activator system. Clin Cancer Res 2014;20:1477-88

72. Xia L, Huang W, Tian D, Zhang L, Qi X, Chen Z, Shang X, Nie Y, Wu K. Forkhead box Q1 promotes hepatocellular carcinoma metastasis by transactivating ZEB2 and VersicanV1 expression. Hepatology 2014;59:958-73.

73. Song Y, Li J, Zhu Y, Dai Y, Zeng T, Liu L, Li J, Wang H, Qin Y, Zeng M, Guan XY, Li Y. MicroRNA-9 promotes tumor metastasis via repressing E-cadherin in esophageal squamous cell carcinoma. Oncotarget 2014;5:11669-80.

74. Lin YH, Wu MH, Liao CJ, Huang YH, Chi HC, Wu SM, Chen CY, Tseng YH, Tsai CY, Chung IH, Tsai MM, Chen CY, Lin TP, Yeh YH, Chen WJ, Lin KH. Repression of microRNA-130b by thyroid hormone enhances cell motility. $J$ Hepatol 2015;62:1328-40.

75. Zhang JP, Zeng C, Xu L, Gong J, Fang JH, Zhuang SM. MicroRNA-148a suppresses the epithelial-mesenchymal transition and metastasis of hepatoma cells by targeting Met/Snail signaling. Oncogene 2014;33:4069-76.

76. Izumchenko E, Chang X, Michailidi C, Kagohara L, Ravi R, Paz K, Brait M, Hoque MO, Ling S, Bedi A, Sidransky D. The TGFbeta-miR200-MIG6 pathway orchestrates the EMT-associated kinase switch that induces resistance to EGFR inhibitors. Cancer Res 2014;74:3995-4005.

77. Ma J, Fang B, Zeng F, Ma C, Pang H, Cheng L, Shi Y, Wang H, Yin B, Xia J, Wang Z. Down-regulation of miR-223 reverses epithelial-mesenchymal transition in gemcitabine-resistant pancreatic cancer cells. Oncotarget 2015;6:1740-9.

78. Huang N, Wu Z, Lin L, Zhou M, Wang L, Ma H, Xia J, Bin J, Liao Y, Liao W. MiR-338-3p inhibits epithelial-mesenchymal transition in gastric cancer cells by targeting ZEB2 and MACC1/Met/Akt signaling. Oncotarget 2015;6:15222-34.

79. Harazono Y, Muramatsu T, Endo H, Uzawa N, Kawano T, Harada $\mathrm{K}$, Inazawa J, Kozaki K. miR-655 Is an EMT-suppressive microRNA targeting ZEB1 and TGFBR2. PLoS One 2013;8:e62757. 